\title{
Characterization of Fibre Reinforced Bituminous
} Mixes

\author{
B. Gopi Raju ${ }^{1}$, K. Naga Sreenivasa Rao ${ }^{2}$ \\ ${ }^{1}$ Assistant Professor, Department of Civil Engineering, Chalapathi institute of technology, Guntur, Andhra Pradesh, India \\ ${ }^{2}$ Assistant Professor, Department of Civil Engineering, Chalapathi institute of technology, Guntur, Andhra Pradesh, India
}

\begin{abstract}
A pavement structure can be designed either as a flexible pavement or a rigid pavement based on its structural behavior, with flexible pavements being widely preferred in India due to its advantages over rigid pavements and economy. Stone Mastic Asphalt is a gap graded bituminous mixture containing a high proportion of coarse aggregate and filler, with relatively little sand sized particles. In the present study, an attempt has been made to study the effects of use of a naturally and locally available fiber called COIR fiber is used as stabilizer in SMA For preparation of the mixes aggregate gradation has been taken as per MORTH Specification, binder content has been varied from 5\% to 7\%. Fiber content varied from SMA $0.2 \%, 0.3 \%$ and $0.4 \%$ and the fiber length varied from $10 \mathrm{~mm}$ and $15 \mathrm{~mm}$. Different performance tests conducted on SMA Mix are Marshall Stability test, drain down test, Indirect Tensile test, Moisture Susceptibility, Repeated Load test with rest period. The specimens for these tests were prepared by Marshall Compaction method. All the tests were carried out for the aggregate gradation of SMA used for wear course in order to study the Characterization on fiber reinforced bituminous mixes.
\end{abstract}

Keywords: Stone Mastic Asphalt, Coir Fiber, Marshall Stability, IDT, Drain Down, Repeated load test.

\section{Introduction}

Flexible pavements have low or negligible flexural strength and are rather flexible in their structural action under the loads. These pavements are layered structures with the following component layers.

- Soil subgrade

- Sub base

- Base Course

- Surface Course

The layered pavement structure transmits vertical or compressive stresses to the lower layers by grain to grain transfer through the points of contact in the granular structure with strong graded aggregates and should transfer the compressive stresses to a wider area. In light of the above factors, it can be learnt that bituminous mix is one of the best flexible pavement layer materials. Bituminous mix is generally used as a surface course and wearing course in flexible pavements since it is necessary that the wearing course must provide a smooth riding surface that is dense and at the same time take up wear and tear due to traffic.

Stone Mastic Asphalt is a gap graded bituminous mixture containing a high proportion of coarse aggregate and filler, with relatively little sand sized particles. It has low air voids with high levels of macro texture when laid, resulting in a waterproof layer with good surface drainage (BCA 9808, 1999).Stabilizing additives are needed in the mastic which is rich in binder content to prevent the binder from draining down from the mix. Polymers and fibres are the commonly used stabilizing additives in SMA. Research and experience have shown that fibers tend to perform better than polymers in reducing the drain down.

Stone mastic asphalt has indicated more durability as a surface asphalt concrete. Some of positive properties of SMA mixtures comprise its high rut resistance, high skid resistance, high durability, improved resistance to reflective cracking, better drainage condition

\section{Review of Literature}

Brown (1994) studied on SMA using different type of filler, stabilizer and concluded that Drain down in SMA is affected by type of filler, type of stabilizer, amount of stabilizer (higher the amount of stabilizer lower the drain down).Optimum binder content of SMA mixes is greater than DGM.

Kumaraj et al. (2004) carried laboratory study using natural rubber powder with $80 / 100$ bitumen in SMA by wet process as well as dense graded bituminous mix with cellulose fibre and stone dust and lime stone as filler and found its suitability as SMA mix through various tests.

K. Thulasirajan and V.I. Narasimha (2011) used as coir fibre in Bituminous concrete and found coir fibre showed improved Marshall Stability. In that study $60 / 70$ penetration grade bitumen with fibre proportions $0.3 \%, 0.5 \%$ and $0.7 \%$ by weight of aggregate and length varied $10 \mathrm{~mm}, 15 \mathrm{~mm}$ and $20 \mathrm{~mm}$.

\section{Objectives}

1) To determine the optimum binder content

2) To obtain the dosage of fibres through characterization of bituminous mixes with respect to Fatigue behavior, Rutting resistance, and Moisture susceptibility.

\section{Volume 4 Issue 12, December 2015}




\section{International Journal of Science and Research (IJSR) \\ ISSN (Online): 2319-7064}

Index Copernicus Value (2013): 6.14 | Impact Factor (2014): 5.611

\section{Material Characterization}

\subsection{Tests on Aggregates}

The coarse aggregate used was a normal weight aggregate with a maximum size of $13 \mathrm{~mm}$. Stone dust was used as the filler. Salient properties of the aggregates as determined by standard tests are given in Table 1.

Table 1: Material Characterisation of Aggregates

\begin{tabular}{|c|c|c|c|c|}
\hline $\begin{array}{c}\text { S. } \\
\text { No. }\end{array}$ & Test & $\begin{array}{c}\text { Morth } \\
\text { Specification }\end{array}$ & $\begin{array}{c}\text { Test } \\
\text { Value }\end{array}$ & BIS Test Method \\
\hline 1 & Impact value (\%) & $<30$ & 27.4 & IS 2386 Part IV \\
\hline 2 & Crushing value (\%) & $<30$ & 27.9 & IS 2386 Part IV \\
\hline 3 & $\begin{array}{c}\text { Los Angeles Abrasion } \\
\text { value (\%) }\end{array}$ & $<30$ & 29 & IS 2386 Part IV \\
\hline 4 & $\begin{array}{c}\text { Water Absorption } \\
\text { Value (\%) }\end{array}$ & $<2$ & 0.27 & IS 2386 Part III \\
\hline 5 & Specific Gravity test & $2.5-3$ & 2.72 & IS 2386 Part III \\
\hline 6 & Combined Index (\%) & $<30$ & 20 & IS 2386 Part I \\
\hline 7 & Angularity number & $0-11$ & 7 & IS 2386 Part I \\
\hline
\end{tabular}

\subsection{Tests on Binder}

VG 30 grade of bitumen is used as the binder and its properties as determined by standard test procedures are tabulated in Table .2

Table 2: Material Characterisation of Bitumen

\begin{tabular}{|c|c|c|c|c|}
\hline $\begin{array}{c}\text { S. } \\
\text { No }\end{array}$ & Test & $\begin{array}{c}\text { Permissible } \\
\text { value }\end{array}$ & $\begin{array}{c}\text { Test } \\
\text { value }\end{array}$ & $\begin{array}{c}\text { BIS Test } \\
\text { Method }\end{array}$ \\
\hline 1 & Penetration value $25^{\circ} \mathrm{c}$ & $50-70$ & 62 & IS 1203-1978 \\
\hline 2 & Softening point, ${ }^{\circ} \mathrm{c}$ & $>50$ & 48.45 & IS 1205-1978 \\
\hline 3 & Ductility value at $27^{\circ} \mathrm{c}, \mathrm{cm}$ & $>75$ & $>100$ & IS 1208-1978 \\
\hline 4 & Specific gravity & $>0.99$ & 1.02 & IS 1202-1978 \\
\hline
\end{tabular}

\subsection{Gradation}

Table 3: Aggregate gradation for SMA

\begin{tabular}{|c|c|c|}
\hline $\begin{array}{c}\text { Sieve size, } \\
\mathrm{mm}\end{array}$ & $\begin{array}{c}\text { Cumulative \% by weight of } \\
\text { total aggregate passing }\end{array}$ & Middle value \\
\hline 19 & 100 & 100 \\
\hline 13.2 & $90-100$ & 95 \\
\hline 9.5 & $50-75$ & 62.5 \\
\hline 4.75 & $20-28$ & 24 \\
\hline 2.36 & $16-24$ & 20 \\
\hline 1.18 & $13-21$ & 17 \\
\hline 0.6 & $12-18$ & 15 \\
\hline 0.3 & $10-18$ & 14 \\
\hline 0.075 & $8-12$ & 10 \\
\hline
\end{tabular}

\subsection{Properties of Coir Fibre}

\begin{tabular}{|l|l|}
\hline Property & Value \\
\hline Diameter (mm) & $0.1-0.4$ \\
\hline Density (g/cm3) & $0.67-1.0$ \\
\hline Natural moisture content (\%) & $11.44-15.85$ \\
\hline Tensile strength (mpa) & $108.26-251.90$ \\
\hline Water absorption (\%) & $85-135$ \\
\hline Modulus of elasticity (Gpa) & $2.5-4.5$ \\
\hline Strain at failure (\%) & $13.7-41.0$ \\
\hline
\end{tabular}

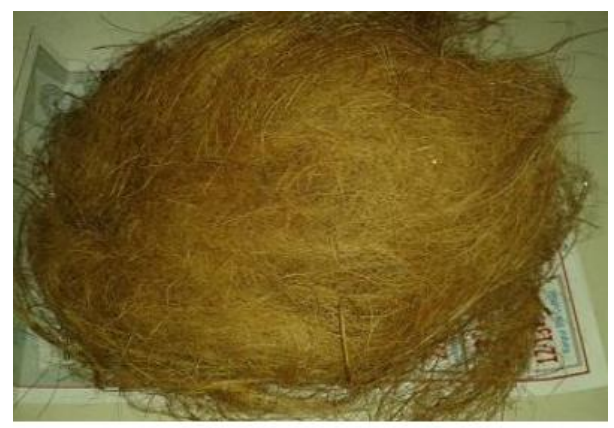

Figure 1: Coir Fibre

\section{Laboratory Mix Design and Analysis}

\subsection{Marshall Stability Test}

Marshall Stability test was conducted to determine the optimum binder content of fibre reinforced SMA $100 \mathrm{~mm}$ dia and $63.5 \mathrm{~mm}$ height by applying 50 blows on SMA each face as per ASTM procedure (ASTM D1559, 2004). In these tests $\%$ binder content was varied from SMA $5 \%$ to $7 \%$ with 0.5 $\%$ increments with varying $\%$ fibre dosage from SMA 0.2 to $0.4 \%$ by weight of mix. The procedure adopted for the preparation of Marshall Specimen was the same as used in the conventional dense graded mixtures, with the change that, coated fibres are added in heated aggregate prior to mixing them with heated asphalt. The mixing and compaction temperatures were kept at $165^{\circ} \mathrm{C}$ and $150^{\circ} \mathrm{C}$ respectively. The compacted specimen was allowed to cool down to room temperature before extraction of the sample of specimen.

Table 5: Parameters at $\mathrm{OBC}$ for various fiber contents at 10 $\mathrm{mm}$ length coir fibre

\begin{tabular}{|c|c|c|c|c|c|}
\hline Properties & $\begin{array}{c}0 \% \\
\text { fibre }\end{array}$ & $\begin{array}{c}0.2 \% \\
\text { fibre }\end{array}$ & $\begin{array}{l}0.3 \% \\
\text { fibre }\end{array}$ & $\begin{array}{l}0.4 \% \\
\text { fibre }\end{array}$ & $\begin{array}{l}\text { Specified } \\
\text { Value }\end{array}$ \\
\hline Stability $(\mathrm{KN})$ & 13.312 & 14.114 & 16.237 & 13.576 & 6.20 \\
\hline Flow $(\mathrm{mm})$ & 5.96 & 5.02 & 4.32 & 5.26 & $2-4$ \\
\hline $\begin{array}{c}\text { Bulk } \\
\text { density }(\mathrm{gm} / \mathrm{cc})\end{array}$ & 2.445 & 2.449 & 2.452 & 2.452 & \\
\hline VFB & 85.256 & 86.022 & 86.611 & 86.655 & 75 \\
\hline VMA & 16.869 & 16.733 & 16.642 & 16.631 & 17 \\
\hline$\%$ of Air voids & 2.5 & 2.339 & 2.233 & 2.22 & $2-5$ \\
\hline
\end{tabular}

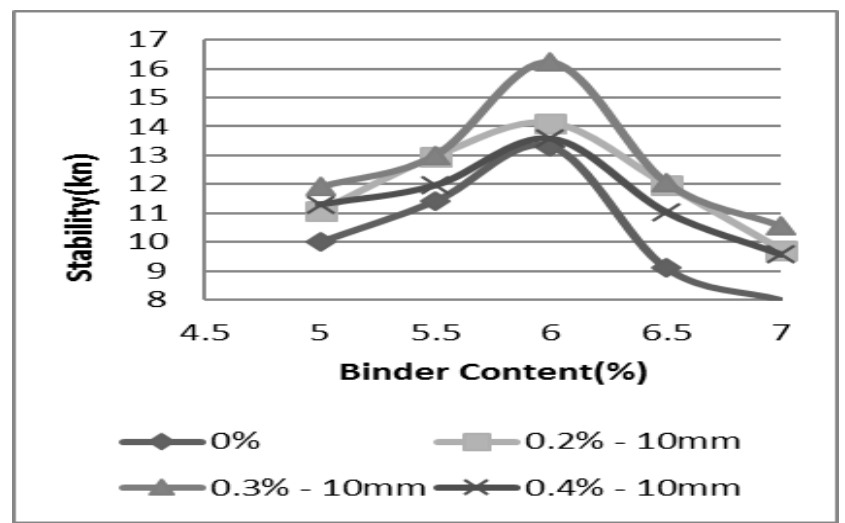

Figure 2: Stability vs Binder content (\%) 


\section{International Journal of Science and Research (IJSR) \\ ISSN (Online): 2319-7064}

Index Copernicus Value (2013): 6.14 | Impact Factor (2014): 5.611

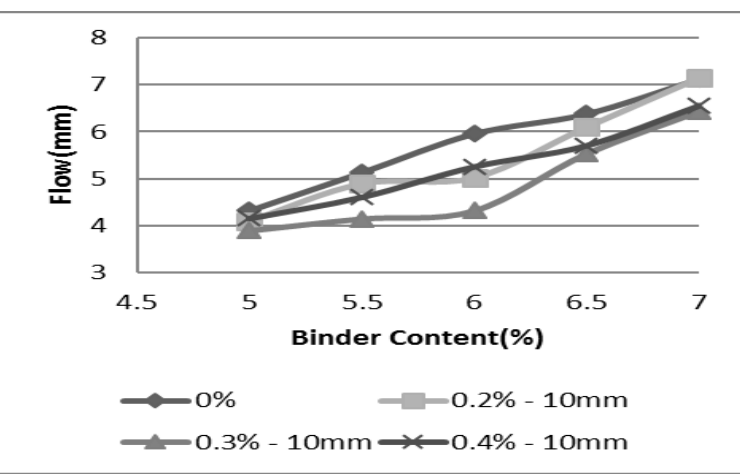

Figure 3: Flow vs Binder content (\%)

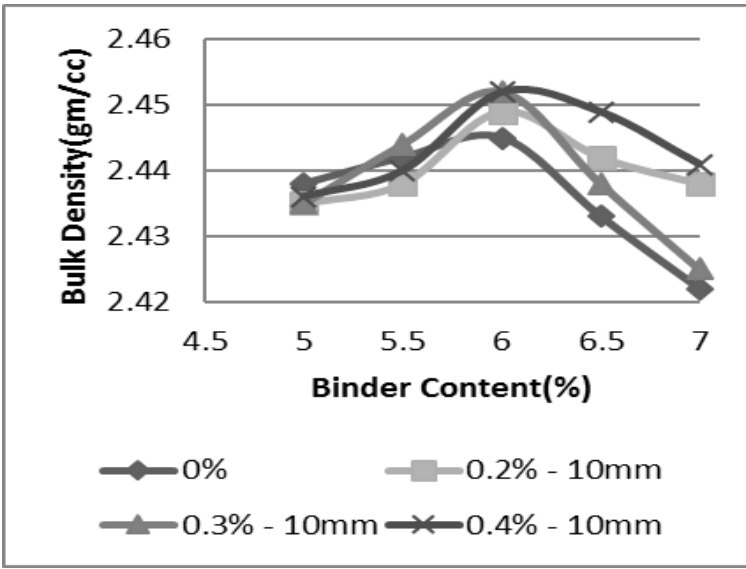

Figure 4: Bulk density vs Binder content (\%)

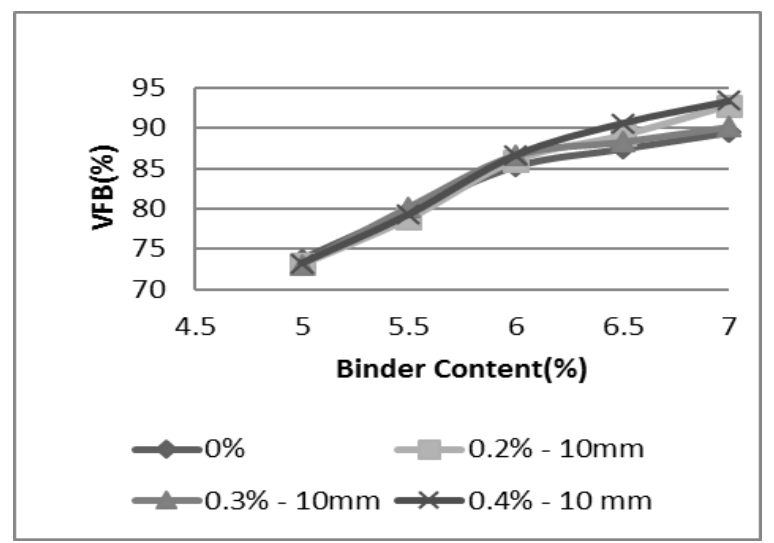

Figure 5: VFB vs Binder content (\%)

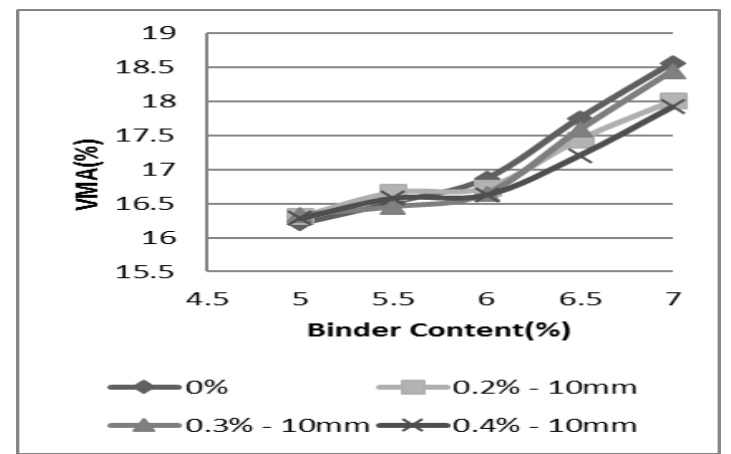

Figure 6: VMA vs Binder content (\%)

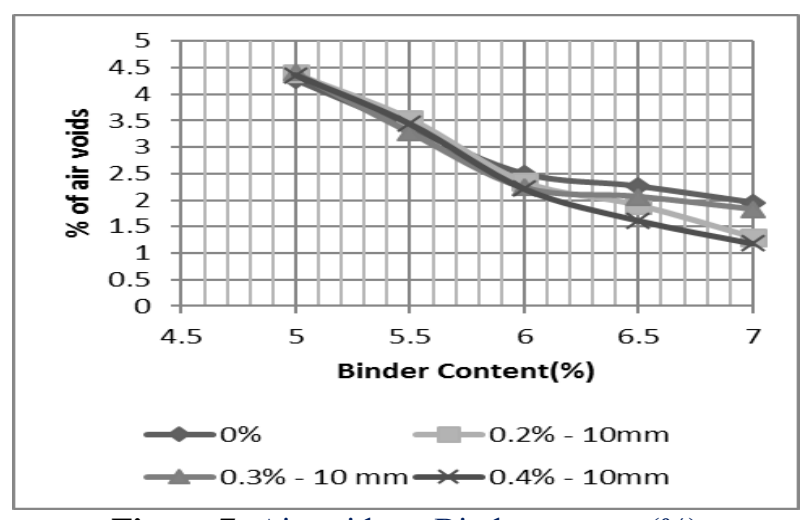

Figure 7: Air voids vs Binder content (\%)

Table 6: Parameters at $\mathrm{OBC}$ for various fiber contents at 15 mm length coir fibre

\begin{tabular}{|c|c|c|c|c|c|}
\multicolumn{7}{c|}{ mm length coir fibre } \\
\hline & $\begin{array}{c}0 \% \\
\text { fibre }\end{array}$ & $\begin{array}{c}0.2 \% \\
\text { fibre }\end{array}$ & $\begin{array}{l}0.3 \% \\
\text { fibre }\end{array}$ & $\begin{array}{c}0.4 \% \\
\text { fibre }\end{array}$ & $\begin{array}{c}\text { Specified } \\
\text { Value }\end{array}$ \\
\hline Stability $(\mathrm{KN})$ & 13.312 & 12.829 & 11.895 & 10.17 & 6.20 \\
\hline Flow (mm) & 5.96 & 5.18 & 4.94 & 4.85 & $2-4$ \\
\hline $\begin{array}{c}\text { Bulk } \\
\text { density }(\mathrm{gm} / \mathrm{cc})\end{array}$ & 2.445 & 2.457 & 2.454 & 2.438 & \\
\hline VFB & 85.256 & 87.749 & 87.714 & 83.769 & 75 \\
\hline VMA & 16.869 & 16.461 & 16.574 & 17.107 & 16 \\
\hline$\%$ of Air voids & 2.5 & 2.02 & 2.153 & 2.779 & $2-5$ \\
\hline
\end{tabular}

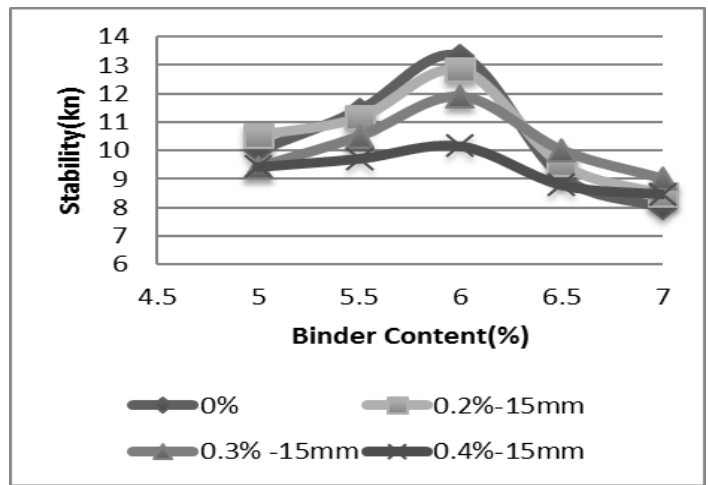

Figure 8: stability vs Binder content (\%)

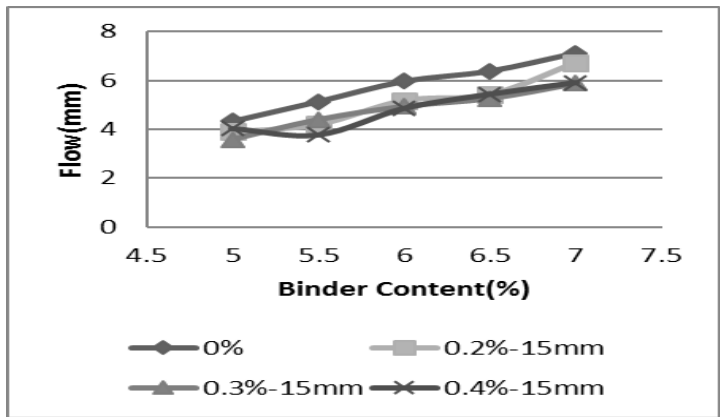

Figure 9: Flow vs Binder content (\%)

\section{Volume 4 Issue 12, December 2015}




\section{International Journal of Science and Research (IJSR) \\ ISSN (Online): 2319-7064}

Index Copernicus Value (2013): 6.14 | Impact Factor (2014): 5.611

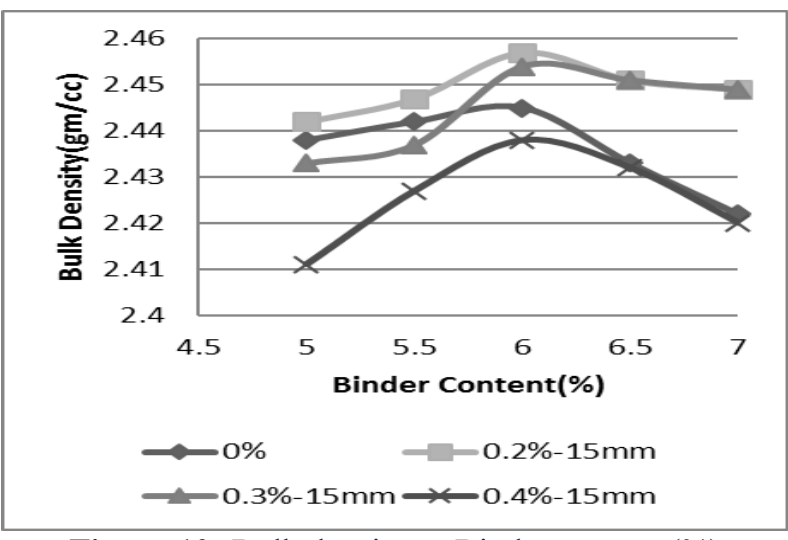

Figure 10: Bulk density vs Binder content (\%)

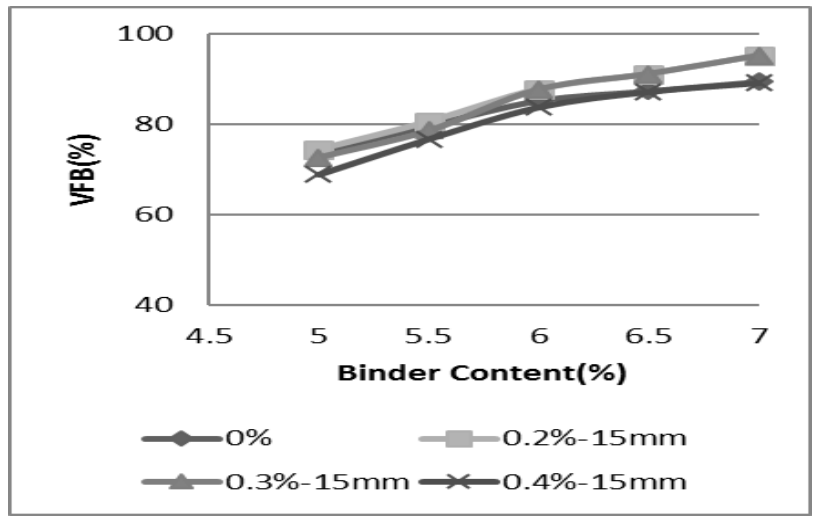

Figure 11: VFB vs Binder content (\%)

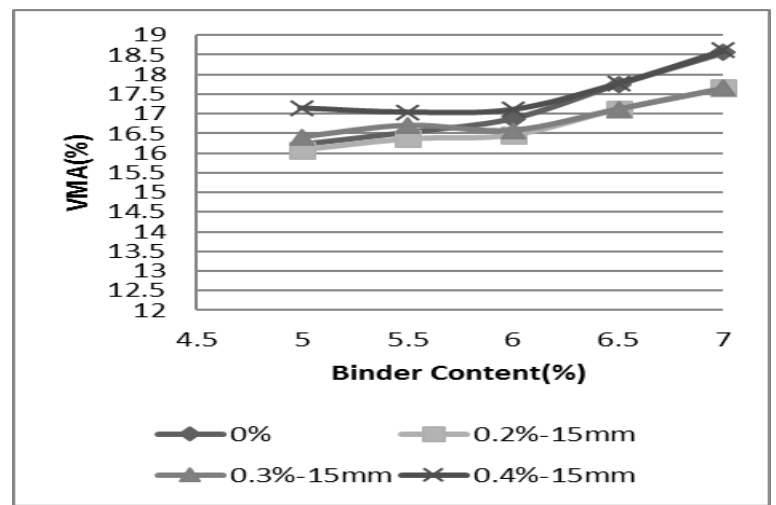

Figure 12 : VMA vs Binder content (\%)

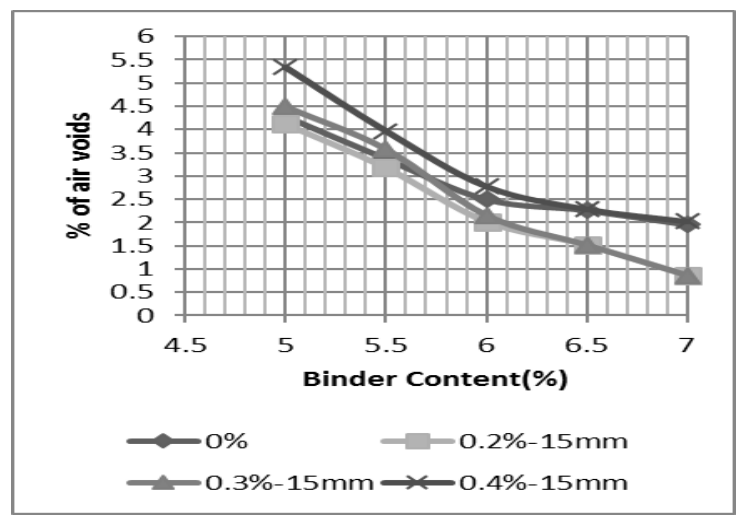

Figure 12: Air voids vs Binder content( $\%)$

\subsection{Drain down Test}

Drain down test developed by National Center for Asphalt Technology (NCAT) is applicable for SMA Mix and was used to determine the efficiency of the additives as stabilizers to prevent the drain down of the binder (Dias Leal et.al, 2008). A standard cylindrical shaped basket $165 \mathrm{~mm}$ tall and $108 \mathrm{~mm}$ diameter is constructed using standard $2.36 \mathrm{~mm}$ wire mesh (AASHTOM92). The sample is prepared according to the Marshall Mix procedure. The uncompacted SMA Mix of known weight is transferred into the wire basket. Leave the sample undisturbed. Place the basket on the paper plate of known weight and place the assembly in an oven at a temperature of170 to 175 degree Celsius (AASHTO T 245) for about one hour. After an hour, remove the basket and paper plate. Record the weight of the paper plate. Any aggregate particles outside the basket should be added back into the mix. The test results are shown in Table 7 , and the optimum fibre content is found to be $0.3 \%$ to bring the drain down to the specified limits of $0.3 \%$ by weight of the mixture. The amount of binder drain down was calculated by Equation 1:

Drain down $(\%)=\frac{B-A}{W} \times 100$

Where:

$\mathrm{A}=$ Initial plate mass

$\mathrm{B}=$ Weight of plate plus drained materials

$\mathrm{W}=$ Loose sample mass

\section{binder content at $\mathbf{5 . 7 5 \%}$}

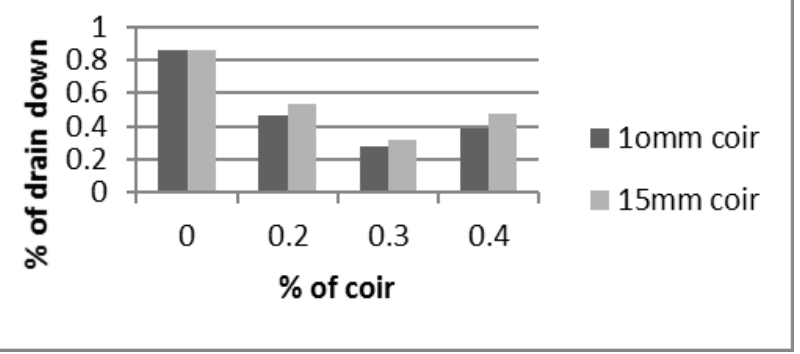

Figure 14: Drain down vs \% of Coir

\subsection{Indirect Tensile Strength Test}

The SMA is not nearly as strong in tension as it is in compression, SMA tensile strength is important in pavement applications. Tensile strength is typically used as a SMA performance measure for pavements. The IDT strength of bituminous mixes is conducted by loading a cylindrical specimen across its vertical diametric plane at a specified rate of deformation and test temperature. The peak load at failure is recorded and used to calculate the IDT strength of the specimen. The samples were prepared in the same manner as that of Marshall Method. Three unconditioned and three conditioned specimens were tested from each group. The conditioned specimens were placed in water bath at $60^{\circ} \mathrm{c}$ for 24 hours and then kept in a water bath for $1 \mathrm{~h}$ at $25^{\circ} \mathrm{c}$ prior to testing. The indirect tensile test was carried out as per ASTM: D6931-07.The test was conducted at $25^{\circ} \mathrm{c}$ temperature and the rate of loading was $50 \mathrm{~mm}$ per minute. Indirect tensile strength of specimen is calculated by using equation 2.

$$
\begin{aligned}
& \text { IDT }(\mathrm{Kpa})=\frac{2 p}{\pi t d} \\
& \mathrm{P}=\text { Maximum load (n) }
\end{aligned}
$$

\section{Volume 4 Issue 12, December 2015}




\section{International Journal of Science and Research (IJSR) \\ ISSN (Online): 2319-7064}

Index Copernicus Value (2013): 6.14 | Impact Factor (2014): 5.611

$\mathrm{t}=$ Specimen thickness $(\mathrm{mm})$

$\mathrm{d}=$ Specimen diameter $(\mathrm{mm})$.

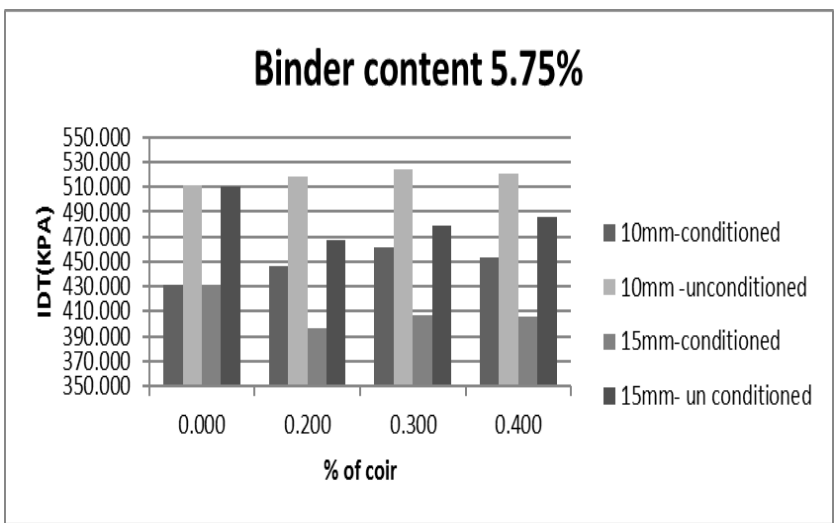

Figure 15: IDT vs \% 0f coir

\subsection{Moisture Sensitivity Test}

Moisture damage in asphalt pavements has been considered to be a widespread problem, which leads to premature failure of the flexible pavements. The loss of cohesion and adhesion are more prominent to the process of stripping. A reduction in cohesion results in a reduction in strength and stiffness. The loss of adhesion is the physical separation of the bitumen and aggregate, primarily caused by the action of moisture damage. In the case of moisture damage measurement, tensile strength is one of the most critical parameters to be always taken into consideration for performance evaluation. Tensile strength Ratio (TSR) is calculated by using equation 3 . $\operatorname{TSR}(\%)=\frac{S 2}{S 1} \times 100$

$\mathrm{S} 1=$ Indirect tensile strength of unconditioned specimen. $\mathrm{S} 2=$ Indirect tensile strength of conditioned specimen.

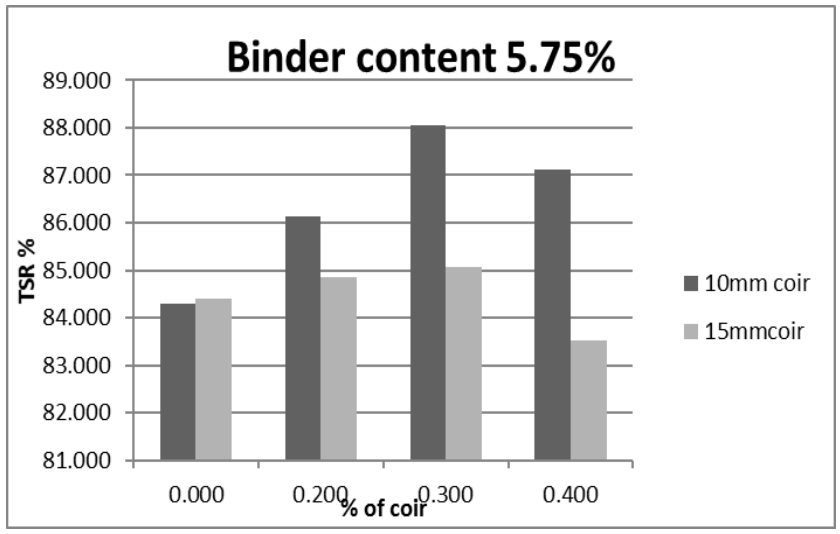

Figure 16: TSR \% vs \% of coir

\section{Conclusions}

The potential of coir fibre as an additive in SMA has been studied in this paper. The percentage fibre content in SMA is varied from 0.2 to $0.4 \%$ with increments of $0.1 \%$ for different series of tests. Analyzing the results, following conclusions has been drawn:

1) The addition of $0.3 \%$ fibre is found to be the optimum fibre content in SMA

2)The Marshall Stability value of SMA with optimum fibre content was found to be $16.237 \mathrm{KN}$, which is higher than the prescribed value of $6.20 \mathrm{KN}$ and the percentage increase in stability value has been found to be $22 \%$ as compared to the conventional mix.

3) The flow value of SMA with $0.3 \%$ fiber and $10 \mathrm{~mm}$ length fibre was found to be $4.32 \mathrm{~mm}$ where as the flow value for conventional mix is $5.96 \mathrm{~mm}$.

4) The drain down test results indicated that coir fibre can retard the drain down of the binder and the $10 \mathrm{~mm}$ length and $0.3 \%$ fibre gives the good results compared to conventional mix.

5) The indirect tensile strength indicates that $10 \mathrm{~mm}$ and $0.3 \%$ of coir fibre mixes was found to be higher by $2.56 \%$ than conventional mix.

6) The Tensile Strength Ratio indicates $10 \mathrm{~mm}$ and $0.3 \%$ of coir fibre mixes was found to be higher by $4 \%$ than conventional mix.

\section{References}

[1] AAPA Asphalt Guide, (2002) "Stone Mastic Asphalt Surfacing", Austroads.And Pavement Design, volume 5, No. 2, pp 239-249.1.

[2] Brown E.R, John E. Haddock, Rajib B. malice, (2008). "Development of mixture design procedure for Stone Mastic Asphalt (SMA)" .

[3] Veeraragavan A, Punith V.S, (2004)"Fatigue behavior of bituminous paving mixtures under repeated loading conditions by Indirect Tensile Test, Research Paper" NBM \& CW, pp. $14-24$.

[4] Vikas Sharma, Shweta Goyal, (2006), "Comparative study of performance of natural fibres and crumb rubber modified stone matrix asphalt mixtures", Canadian Journal of Civil Engineering, February, Vol.33, (2), pp134.

[5] Beenak's and Bindu c s (2011) "coir fiber as a stabilizing additive in stone mastic asphalt". International Journal of Earth sciences and Engineering, volume 04 .pp 165-177

[6] Brown E.R. and Manglorkar H. (1993), "Evaluation of Laboratory Properties of SMA mixtures", NCAT Report No. 93-5, Auburn University, Alabama

[7] Subramanian T,2012, "Experimental Investigation on coir fiber reinforced Bituminous mixes" International Journal of Engineering Research and Applications ( IJERA), volume 2, pp 1794- 1804

[8] Thulasirajan k, V L Narasimha 2011, "Studies on coir fiber reinforced bituminous concrete". International Journal of Engineering Research and Applications (IJERA).volume 06. Pp 835-838.

[9] ASTM D 6931 (2007), "Indirect Tensile (IDT) Strength for Bituminous Mixtures"

[10] Tap kin, S., et al (2009) Repeated Creep Behavior of Polypropylene Fibre Reinforced Bituminous Mixtures. Journal of Transportation Engineering, Turkey.

[11] Abdul-Aziz Maher , Mohamed Rehan Karim ," Prospect Of Using Glass fibre Reinforced Bituminous Mixes ", Journal of the Eastern Asia Society for Transportation Studies, (5), 794-807(2003). 